\title{
Market Structure and Heterogeneous Traders' Strategies within an Environment of Information Asymmetry
}

\author{
Mosbeh $\mathrm{Hsini}^{1}$ \\ ${ }^{1}$ Higher Institute of Trade and Accounting of Bizerte, Carthage University, Tunisia \\ Correspondence: Mosbeh Hsini, Higher Institute of Trade and Accounting of Bizerte, Carthage University, \\ Tunisia. E-mail: lahsinim@gmail.com
}

Received: May 8, 2015

Accepted: May 22, 2015

Online Published: July 25, 2015

doi:10.5539/ijef.v7n8p103

URL: http://dx.doi.org/10.5539/ijef.v7n8p103

\begin{abstract}
This paper aims at containing the puzzle of heterogeneous strategies of several operators on tunisian securities market, in an asymmetric information framework. We attempt to explore to what extent unlike information does shape the reactions and behaviors when operating over such a market. Moreover, we highlight the fact that when uncertainty is ruling the market, much of its operators are irrational and accordingly their transacting loose reason and wisdom. Our objective is to test whether irrationality may lead to such an excessive volatility, which paves the way towards our empirical investigation driven on the tunisian stock market data for the period (1969-2005) through the Shiller (2001) variance bounds tests. The results show such a dramatically violation of all the three inequalities and then an excessive volatility within stock returns.
\end{abstract}

Keywords: asymmetric information, irrationality, stock prices, volatility

\section{Introduction}

Several major obstacles that confront rational expectation theory contributed to the undermining of market efficiency. Accordingly, fully efficient markets characterized by the impossibility to forecast such stock price variations have relatively let the place to professional markets where it is easy to make profits on the basis of more/less privileged informations. Considering the fact that information is neither free nor easy and especially not identically distributed among the market participants, has significantly contributed to such a disparity between operators in regard of information (Stoll, 1989; Biais, Hillion, \& Spatt, 1995; Hasbrouk, 2005; Ai, 2010; Illeditcsh, 2012; Alti \& Lock, 2014). In this framework, the information processing fails, thus some informational asymmetries shall affect the normal market functioning. Financial theory postulates that assets' acquisition generally poses a problem of determining the value at which it must be exchanged. We often talk about "intrinsic value" or "true value" of the assets in the market. In this market imperfection environment, gaps are significantly obvious between stock prices and their fundamental value and thus aggregation of information in prices is not done systematically and correctly. Barberis (2000), Scherbina (2004), state that each listed company must constantly inform the financial community of its contacts with financial analysts (banks, financial institutions, brokers) throughout regularly releases (statements) published in financial press about its important events. The behavior description of certain operators (brokers and investors) is performed by examining their reactions following the demonstration of new events on the market. For instance, the initiated (the well informed), who owing to their positions, they have such an information that others (outsiders or under informed) do not have, and by transacting, information is consequently included in the securities 'price even before it is yet published (Glosten \& Milgrom, 1985; Kyle, 1989).

As intermediaries, they exchange on the basis of temporary fluctuations of stocks supply and demand. In this sense, the market maker is ready to satisfy either a purchase order soon happens (by selling for his own account) or a sale order soon happens (by buying for his own account). In exchange for this immediacy service and for the risk he runs when satisfying whatever demand or offer expressed on the market, the market maker ask for such a remuneration. He offers investors eager to sell, a price slightly lower than the intrinsic value of the security. This is the price at which he satisfies the sellers (the price at which the intermediary buys for his own account): it is the bid price (asked). Conversely, the price at which the intermediary satisfies buyers (the price at which he sells on his own account): it is the ask price (offered). Glosten and Milgrom (1985), Admati and Pfleiderer (1988), Anderson, (1996), Wang (1998), Brockmann and Chung (2000), Ziegler (2001), Lawence and Venkatech (2005), 
Illeditcsh (2012) highlight the complex character of financial information and put the stress on the playing of strategic behavior between diverse agents operating on financial market. Stoll (1985), Glosten and Milgrom (1985) pointed out the consequences of asymmetric information and its adverse effects that may result in the established relationship between well informed operators and under informed ones. The essential idea of this paper is to discuss the different behaviors of market operators, within a framework of informational imperfection.

\section{Operators' Strategic Expectations}

\subsection{Case of Dealer Markets}

The market maker is considered as an ordinary investor who holds a portfolio based on both the opportunities he observes besides his preferences. Providing immediacy to other investors means to him to leave his preferred position in order to satisfy the desires of others. Getting away from his optimal portfolio, the market maker supports such a risk since he moves towards a level of return and risk, which may not match his preferences. The main objective of the market maker is to achieve choosing a spread that maximizes his profit. Roll (1984), Stoll (1989), Biais et al. (1995), Anderson (1996), Bodie and Merton (2001), Ziegler (2001), Scherbina (2004), Hasbrouck (2005), Foucault, Sraer, and Thesmar (2011), Asparouhova, Bessem, and Kalcheva (2013) contributed to the lighting of these concepts. By varying his purchasing and sale prices, this operator can favorably orient the order flow. In this sense, he can either encourage or discourage transactions in one direction or in the other according to his preferences. A "short" intermediary, the one who sold to much and then having a negative equity stock, is well aware that an additional public purchasing does enhance his risk exposure. The attempt to temper this puzzle pushes him to fix the purchase /sale prices as higher as possible. Consequently, he shall discourage those who wish selling. Thus, after a brief time and a somewhat transactions, this agent can restore his expected position (Bazak \& Makarov, 2014). Similarly, by means of the prices he quotes, if this operator has an excessive inventory compared to what he would like, he resorts to a reverse strategy which consists to reduce not only his bid price (buying with) but also his ask price (selling with). Accordingly, this state will generate a decrease in the probability of receiving a sale order and an increase of receiving such a purchase order. This policy of price will allow this market maker to control adequately his position. In fact, these bid-ask prices are function of the market maker position, and then they reflect his personal preferences. In the same vein, this intermediary does not accept this role or assume the risk without being able to impose to the market (investors) such prices that differ from the fundamental value of the exchanged security; which implies a bid price that would be lower (below his estimate of the true value) and an ask price that would be higher (above the true value). In this context, Easley and O'Hara (1987), by analyzing the relation size-price, they highlight that the market maker is able to identify whether the investors is informed or not regarding to their transactions' size. This fact let him ready to review his anticipation on the security value and changes his prices accordingly. He can enlarge his spread so as to protect against the execution of orders coming from agents more informed than him. In a situation of information asymmetry, Kyle (1985) states that market makers face an adverse selection problem when they display their bid-ask prices, because they are not able to distinguish insiders from outsiders over the market. Moreover, several models have followed the Kyle track and therefore exploited the theoretical and empirical implications of his model to examine the strategic behavior of operators on a stock market.

Admati and Pfleiderer (1988) state that investors when arriving on the market ask the market maker about his bid and ask quotes and make accordingly decisions that maximize their expected utility. Therefore, the information of uninformed investors (the outsiders) includes prices of past transactions, bid and ask prices and any publicly available information. Informed investors (insiders) have access to all these informations, besides they are more able to capture some private signals. It is very important to consider that informed trader chooses to buy such a security whenever his information shows that the "true" value is greater than the ask price quoted by the market maker (true price > bid). Thus, this asset is currently considered undervalued and so the insider will make a profit by reselling it later. Conversely, he can sell only if he anticipates that the real price of such security is lower than the bid price of the intermediary (True price < bid price). Thus, this asset is revealed undervalued at the eyes of the same informed investor who sells it at the time $(t)$ for the sake to purchase it later. What about the uninformed investors (outsiders), they agree to buy (sell) at a price higher (lower) than the price that would have prevailed if there was no market frictions, this is related to the satisfaction of their immediate needs for liquidity. If no, they expect the peak moments of trade (open and close moments), where all stakeholders are involved, in order to reduce their losses with the market maker. The insider observes the security value before each auction and can trade at each date. This operator has therefore rational expectations about the strategies of the intermediary. In turn, the latter can benefit from the transactions with uninformed agents, to the extent that he receives the spread between his bid and ask prices. Admati and Pfleiderer (1988) justify the increase in liquidity at the opening and 
closing of the trading session by the strategy of liquidity traders (the outsiders) who choose to focus their orders at that time in order to attract the largest number of informed traders where competition shall reduce the former costs. Similarly, Foster and Viswanathan (1993), (Biais, Hillion, \& Spatt, 1995). provide the same explanation for the effect Monday. Also, Biais (1993) predicts that insider's presence costs expensively for intermediary, since these operators are fully aware about the realization of the future value of the security. Thus, by exchanging with these informed operators, the intermediary is certain to undergo a loss and accordingly, he sets a sufficiently large spread (too wide) for the sake that his losses emanating from insiders will be offset by his gains emanating from outsiders. It is true that the intermediary can profit by trading with outsiders, however he can upside discourage them to undertake more transactions since his spread is quite wide, resulting to a reduction in the trade volume of transactions. This reasoning based on the operator's strategies did not forget to point out that the ability of market makers to expand their spread is limited by the fact that the request for their service has a negative slope

\subsection{Case of Auction Markets}

Bias et al. (1995) and more recently Bodie and Merton (2001) state that patients agents pass limit orders (the highest price offered for sale and the lowest price offered for purchase) motivated by two advantages, one informational and the other the remuneration of immediacy service. These initiated operators wish to exchange and profit then from their informational advantage. Indeed, the signal or the private information they have is perishable insofar as an information publication may reduce this advantage. They are therefore encouraged to pass orders. In this sense, if they pass such orders at the market price, then they may bear the spread cost. This strategy is profitable only if their informational advantage is sufficiently large (highly precise private information or quickly perishable). So, they better be patient and pass an order in the book orders. They wait patiently that a hurry agent comes exercising successively the limits of book. Then, the more their private information is imprecise and the less it is perishable, the more they depart their reserve price of the true price. Leland (1992) highlights that patient agents have a socially beneficial role as they provide liquidity to the market. Indeed, by receiving signals, they are ready to reveal some of their information against remuneration in exchange for liquidity service and the risk of disclosing information to the market. More liquidity needs, the more they ask for a high remuneration. Nevertheless, they could not enlarge their spread indefinitely because the liquidity need is not infinitely elastic. Thus, compensation for donors limit orders in exchange of liquidity service depends on the accuracy of their signal, the volatility of the security and specifically on their risk aversion. The more their signal is imprecise, the more the remuneration required is higher to the extent that they want to protect themselves in order to avoid their orders to be executed by operators more informed than them (Kyle, 1985; Lynch \& Musto, 2003). Once the signal loses precision, patient agents are less willing to use their informational advantage since it does not penalize them excessively, and then they behave more patient. On the contrary, if the signal gains more accuracy, they behave more willing to conduct transactions in order to profit from their informational advantage due to the information perishable character that encourages them to place orders in the book where price does not stray too much from the security fundamental value (Chordia \& Shwaminathan, 1997; Kodres \& Pritsker, 2001; Easley \& O'Hara, 2010; Illeditsch, 2012; Hu et al., 2013; Bazak \& Makarov, 2014). Generally if patient operators have such a very specific signal (perfect), the spread is canceled. Similarly, the security is more volatile, the compensation required by the limit orders donors is stronger. .Moreover, more they are risk averse; they are more demanding in terms of remuneration (Orlean, 1990; Foucault, 1999). It is important to note that the signaling theory is a natural extension of the theory of asymmetric information; from the moment one realizes that markets are not efficient, and operators do not have access to the same information. As a result, some will have an informational advantage over others and will try to enjoy it. Signaling theory is based on the recognition that agents do not have all of the same information. When information is imperfect or asymmetric, a great need for an incentive system is expressed within the market which drives the firm leaders to communicate the right signal. Sometimes, the inaccuracy of public information contained in the securities prices allows some agents to exploit public information and turn it into privileged information. These agents take advantage from the instability phase caused by the arrival of large information flows at the day beginning. Then, they are in a hurry to exchange on the basis of their informational advantage generated from public information.

Thus, those who manage to quickly restate information look for enjoying their informational advantage by making trade very quickly, before prices have truly integrated all information. This fact of exchange will justify the increased transaction volume in early trading. This increase at the opening does not correspond to an increase in volume from ex-ante informed agents, as suggested Admati and Pfleiderer (1998), but rather an increase in the number of agents eager to transact according to privileged information generated from public information. These are agents who have become informed early trading. Informed agents do not exchange early in order to camouflage their transactions (sometimes large), but they are forced to exchange due to the perishable nature of their 
information (Shiller, 1999; Wang, 2003; Ai, 2010). It is important to note that an agent (whether a donor limit orders or a market maker), when setting his spread and the amount he wishes to exchange, risk to undergo an adverse selection cost when performing transactions with agents better informed than him. These transactions convey information and then have a permanent impact on prices (Roll, 1984; Glosten \& Milgrom, 1985; Biais et al., 1995; Ziegler, 2001; Bodie \& Merton, 2001; Benartzy \& Thaler, 2002; Lynch \& Musto, 2003; Linnainmaa, 2010; Illeditcsh, 2012). Accordingly, uninformed or pressed agents, who place a purchase limit order at time t, do not observe the signal, but infer information from the equilibrium price.

\section{Mimicry}

Several models have been developed to explain the similarity of the operators' behaviors, at a given time, in the financial markets. A first category of model uses the fact that the information that operators have is asymmetric and of unlike quality. Thus, uninformed operators try to copy the well-informed (Leland, 1992; Orlean, 1990; Lee, Lin, \& Liu, 1999; Daniel \& Titman, 2008; Bernard \& Morse, 2012). A second class of models assumes irrational or herd behavior of such operators. Orlean (1989) suppose that the new market entrants copy some operators randomly from those present on the market. A third type of models does not introduce, at first sight, asymmetric information or irrational behavior. These are mimetic chain models (Bikhchandani, Hirschleifer, \& Welch, 1992; Barberis et al., 1998; Shiller, 2001; Kogan, Ross, Wang, \& Westerfiled, 2006) where individuals are involved in the market according to such an order.

Those who choose tardily, they do observe not only their private information but also the behavior of their previous (predecessor) operators. This creates a phenomenon of "majority": after a certain number of individuals, the following line up with the opinion of the many precedents and their private information weighs only a negligible weight in their decisions. This mechanism results in a strong increase in the probability that all market operators behave at the same way. In this model of mimetic chain, Daniel and Titman (2008) inquire if operators do have privileged an information with the same quality, why some of them take the "leader" position and the others as "followers" or copiers. Instead, followers, having yet the observation of the leaders' actions, should make better decisions, and thus according to an automatically turnover they may become "leader" instead of precursor leaders. Consequently, the situation is reversed, where the leader becomes a follower and vice versa.This relationship of lead-lag is defined as the act of an operator to change his behavior to match (align) the behavior of the group. Indeed when the uncertainty on the fundamental rules over all operators, it becomes rational for them to seek additional information by monitoring the opinions of others. The result is thus an interaction between opinions that influence each other and converge to polarize the market anticipating such an average opinion (the typical Keynes example of (photos)). Wang and Lo (2007) state that one of the promising developments in the economic and financial literature today is the analysis of irrational and herd behaviors where market participants take simultaneously or nearly simultaneously similar decisions. In this context, three kinds of mimicry can be identified:

* Mimicry results from the fact that many poorly or not informed traders who meet randomly and copy each others. The manner how these meetings will operate influences the final market equilibrium, since more an opinion or information are widespread, the probability they are spreading is greater (the opinions' contagion).

* Mimicry may result from the competitive structure of the market. By adopting a herd behavior, it may reduce the risk of losing markets.

* Mimicry can be rational: the market organization or the information distribution implies that it is rational for some investors or traders to copy others and then forgetting their private information.

\section{Interaction and Opinions' Contagion}

Through random encounters, opinions are transmitted from one individual to another systematically. Orlean (1990), based on the pioneer works of Weidlich and Haag (1980) about the opinions sociology, was able to develop a financial contagion model which describes group dynamics (psychology of the crowd) and more particularly the contagion effects produced by games of interpersonal influences. Shleifer (2000), Wang and Lo (2007), Foucault et al. (2011), Bazak and Makarov (2014) highlight that these mimicry models seem quite reasonable when considering markets' functioning where the small operators are guided by the choices of large operators whom assumed having a better information than themselves. The mimicry phenomenon is obviously a strong source of volatility, and then the market is highly unbalanced and a contagion process that tends to homogenize opinions is a speculative bubble generator phenomenon. The essential contribution of the first theorists bubbles (Blanchard \& Watson, 1984) was precisely to clarify the debate on speculation. Stoll (1985) will link later the bubble concept to that of self-fulfilling expectations. When the security price depends on the anticipation of its future value, it becomes rational to anticipate the expectations. Moreover, Blanchard and Watson (1984) state that the bubble 
increases the variance of the security price. They attribute that excessive volatility exhibited from prices to rational bubbles and even irrational bubbles (fads \& fashions). Shiller (1999) attributes this volatility excess to fashions and fads generated by the noise traders that by intervening massively destabilize markets and amplify volatility.

\section{Empirical Evidence on the Tunisian Stock Market: (Variance Bounds Tests)}

Our task consists to determine whether the prices of securities listed on the Tunisian stock market exhibit excessive volatility which is to test the likelihood of emergence of such speculative waves, via the variance bounds tests initially introduced by Shiller (1981), LeRoy and Porter (1981).

\subsection{Overview of the Model}

Shiller (1981) states that it is possible to define the forecast error as follows:

$$
\mu_{t}=P^{*}{ }_{t}-P_{t}
$$

The variable $\mathrm{P}_{t}$ represents the observed real price; $\mathrm{P}_{t}{ }_{t}$ is the actual security value which is called by Shiller as ex-post rational price. $\mu_{t}$ is orthogonal to $P_{t}$; otherwise, the lack of correlation between $P_{t}$ and $\mu_{t}$ testifies that $P_{t}$ is a rational forecast. This will provide:

$$
\operatorname{Var}\left(P_{t}^{*}\right)=\operatorname{Var}\left(\mu_{t}\right)+\operatorname{Var}(P t)
$$

As long as the variance cannot be negative (since an operator is always positive), it follows that:

$$
\operatorname{Var}\left(P_{t}^{*}\right) \leq \operatorname{Var}\left(\mu_{t}\right)+\operatorname{Var}\left(P_{t}\right)
$$

Consequently, it will be:

$$
\begin{gathered}
\operatorname{Var}(P t) / \operatorname{Var}\left(P_{t}^{*}\right) \leq 1 \\
\sigma(p) \leq \sigma\left(p^{*}\right)
\end{gathered}
$$

This inequality commonly known as the variance bounds tests, advanced by Shiller (1981); LeRoy and Porter in 1981, used to test the model of perfect markets where the variance of securities prices must be bounded by a theoretical value that depends only on the variability of the fundamental determinants of the price. Thus, via this test, it is possible to detect the discrepancy between prices and their fundamental value. That so called divergence is only explained by the presence of excessive volatility.

Previous investigations in this area show that many empirical studies have attempted via the variance bounds tests to validate the existence of excessive volatility in the prices of financial assets. Shiller (1981) in a pioneer work seeking to compare the variation ex post of dividends and the volatility of the S \& P5oo (1971-1979) and the Dow Jones Industrial Average (1928-1979), noted that the prices of financial assets exhibit such an excess volatility relatively to fundamental represented by dividends. Blanchard and Watson (1982) confirmed the presence of this volatility, with a test based on the assumption of stationarity dividends. In addition, Shiller (1984) assumes that the logarithm of dividends (In Dt) follows a random walk and shows that volatility of observed prices exceeds largely that of the fundamental. More recently, Campbell and Shiller (1988) report that the efficient market model is widely violated empirically. West (1988) led to a similar result as precursors for the review of volatility. It follows from the foregoing that the majority of the variance bounds tests significantly confirm that prices fluctuate more than it should have been if the market is efficient.

The model variance bounds tests is expressed through several sample inequalities that will be highlighted as follows:

The first inequality puts a limit on the standard deviation of $\mathrm{p}^{*}$ :

$$
\sigma(p) \leq \sigma(p *)
$$

The second only puts a limit on the standard deviation of $\Delta \mathrm{p}$ in terms of standard deviation of $\mathrm{d}$ :

$$
\sigma(\Delta p) \leq \sigma(d) / \sqrt{ } 2 r
$$

The third also puts a limit on the standard deviation of $\Delta \mathrm{d}$ :

$$
\sigma(\Delta p) \leq \sigma(\Delta d) / \sqrt{ } 2 r 3 /(1+2 r)
$$

Thus, the non-verification of these inequalities reflects the presence of excessive volatility to trigger waves of speculative bubbles in the market. Once these are verified, the volatility of observed prices should not be too large regarding to those of the fundamentals.

\subsection{Assumptions}

We note that these inequalities require the following assumptions: 
H1: The securities prices reflect the operators opinions that express the rational expectations of future dividends.

$\mathrm{H} 2$ : The expected real return rate, $r$, (adjusted for inflation) over the security market is constant in time.

H3: Aggregated real dividends on the security market can be represented by a stationary stochastic process with finite variance.

\subsection{Data and Empirical Procedures}

\subsubsection{Data}

The study on the checking of the volatility of financial assets traded on the Tunisian stock market is conducted on a sample of nine securities including five banks and two insurance companies and two industrial companies, covering a period from 1969 to 2005.The sample selection is dictated by the availability and continuity of stock market data on stock prices and dividends distributed annually. What about the treatment of missing data, we propose to adapt the predecessor method since it involves replacing all missing prices by the last available.

\subsubsection{Methodology}

For the sake to check the existence of excess volatility in the prices of financial assets, we took the approach Shiller (1981) where we are offered to determine firstly the price indices and the dividends per share. Indeed, the stock prices and dividends per share of financial assets comprising our sample are represented by indices artificially constructed through weighting them by market capitalization of each year.

Formally, the price index in year $\mathrm{t}$, denoted $\mathrm{Pt}$ is determined as follows:

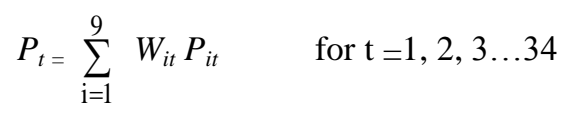

Pit: The share prices of asset $i$ at time $t$.

$\mathrm{W}_{\mathrm{it}}$ : The $\mathrm{W}_{\mathrm{it}}$ coefficient of the market capitalization of asset $\mathrm{i}$ at time $\mathrm{t}$.

This ratio is determined by dividing the market capitalization of asset $i$ on the total market capitalization of all assets composing our sample. In a similar manner, the indices of dividends per share are determined as follows

$$
D_{t}=\sum_{\mathrm{i}=1}^{9} \mathrm{~W}_{\text {it }} D_{i t} \quad \text { for } \mathrm{t}=1,2,3 \ldots 34
$$

$\mathrm{D}_{\mathrm{t}}$ : dividends per share $\mathrm{i}$ at time $\mathrm{t}$.

Once the price indices and dividends per share are determined, it will be wise to calculate the fundamental value or ex-post price defined by Shiller as the rational price that would be obtained if all operators know with certainty the future dividends and when the efficient market model is correct. This fundamental value is derived as an index from the following equation:

$$
\begin{aligned}
R_{t} & =(P t-P t+D t) / P_{t} \\
P t^{*} & =\left(P_{t+1}+D_{t}\right) / 1+R_{t} \\
P_{t-1}^{*} & =\left(P^{*}{ }_{t}+D_{t-1}\right) / 1+R_{t}
\end{aligned}
$$

Throughout this investigation, we propose to use two methods for the determination of $\mathrm{Pt}^{*}$. The first one supposes that $\mathrm{Pt}^{*}$ is equal to the price index of the last year of the considered period as $\mathrm{Pt}$ of the year 200. The second method, as in Shiller (1981) assumes that $\mathrm{P}{ }_{\mathrm{t}}$ is equal to the average over the period (34 years). To outperform these variance bounds tests and so via the verification of these three inequalities [(4), (5), (6)] mentioned above, we take support on two interest rates (for further analysis) which will be assumed to be constant over the entire period as in the study of Shiller (1981). The first rate is the average of the State borrowing rates issued in 1967 (5\%) and the equipment bonds issued in 1987 (6.5\%), giving an average rate $\mathrm{r}=$ $5.75 \%$. The second rate is that of the average stock returns $\mathrm{r} 2=11.5 \%$.

\section{Results and Interpretations}

It is important to note that in the Shiller methodology (1981) $\mathrm{P}_{\mathrm{t}}{ }_{\mathrm{t}}$ is assumed equal to the average of Pt over the entire period; while in the second method (derivative method), $\mathrm{P}{ }_{\mathrm{t}}$ is equal to the terminal value of Pt. Thus, with Shiller variances bounds tests that consists validating the three above mentioned inequalities [(4), (5), (6)].

$$
\begin{gathered}
\sigma\left(p_{t}\right) \leq \sigma\left(p_{t}{ }^{*}\right) \\
\sigma(\Delta p) \leq \sigma(d) / \sqrt{ } 2 r
\end{gathered}
$$




$$
\sigma(\Delta p) \leq \sigma(\Delta d) / \sqrt{ } 2 r^{3} /(1+2 r)
$$

Thus, for price indices and dividend per share series of the nine securities listed on the Tunisian stock market and for a period stretching from 1969 to 2005, we produced the following results:

For the inequality $(1): \sigma(\mathrm{pt}) \leq \sigma\left(\mathrm{P}_{\mathrm{t}}\right)$

The standard deviation for $\mathrm{Pt}$ is $\sigma(\mathrm{pt})=11.85699$.

The standard deviation of $\mathrm{P}_{\mathrm{t}}$ is $\left[\sigma\left(\mathrm{P}^{*} \mathrm{t}\right)\right]$ which is expressed in the following table:

Table 1. The standard deviation of $\mathrm{P}_{\mathrm{t}}$ for the Shiller method and the derivative one

\begin{tabular}{lcc}
\hline & & The standard deviation of $\mathrm{pt} * \sigma(\mathrm{pt} *)$ \\
\hline Shiller method & 7.816322 & 7.431551 \\
derived method & 6.949586 & 6.695717 \\
\hline
\end{tabular}

Given the $\sigma(\mathrm{pt})$ value $=11,85.699$, it will be reasonable to deduct from this table that $\sigma$ values: $\sigma\left(\mathrm{P}_{\mathrm{t}}\right)$ issued from the two methods are significantly lower than $\sigma(\mathrm{pt})$ found above, constituting a substantially violation of the first inequality.

This variance bounds model postulates that in a perfect market, the price variance of a financial asset is considered to be bounded by a theoretical value that depends only on the variability of the fundamental determinants of such a price. This test allows detecting a divergence between the observed prices and their fundamental values. The so-called discrepancy drains its essence from the presence of excessive volatility that may cause waves of speculative bubbles.

For the second inequality $(2): \sigma(\Delta \mathrm{p}) \leq \sigma(\mathrm{d}) / \sqrt{2 r}$

The standard deviation of $(\Delta \mathrm{p})$ is $\sigma(\Delta \mathrm{p})=5.158392$.

The standard deviation of $\left(\mathrm{d}_{\mathrm{t}}\right)$ is $\sigma\left(\mathrm{d}_{\mathrm{t}}\right)=0.194833$.

While $\sigma(\mathrm{d}) / \sqrt{2 r}$ value is given by the following Table 2 .

Table 2. The standard deviation of (d) $/ \sqrt{2 r}: \sigma$ (d) $/ \sqrt{2 r}$ for the Shiller method and the derivative one

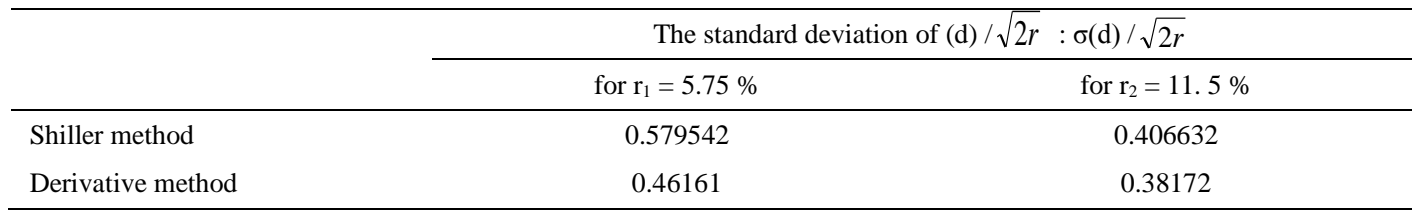

As $\sigma(\Delta p)=5.158392$, it is much higher than the values of the second inequality which is also widely violated and seems to confirm again the existence of excessive volatility.

For the third inequality (3): $\sigma(\Delta \mathrm{dt}) / \sqrt{2 r^{3}} /(1+2 \mathrm{r})$

The standard deviation $(\Delta \mathrm{pt})$ is $\sigma(\Delta \mathrm{pt})$ is always equal to 5.158392 .

The standard deviation $(\Delta \mathrm{dt})$ is $\sigma(\Delta \mathrm{pt})=0.055979$.

Thus, $\sigma(\Delta \mathrm{dt}) / \sqrt{2 r^{3}} /(1+2 \mathrm{r})$ is given by the following table 3 :

Table 3. The standard deviation $(\Delta \mathrm{dt}) / \sqrt{2 r^{3}} /(1+2 \mathrm{r})$ for the method of Shiller and that derived one

\begin{tabular}{lcc}
\hline & \multicolumn{2}{c}{ The standard deviation of $(\Delta \mathrm{dt}): \sigma(\Delta \mathrm{dt}) / \sqrt{2 r^{3}} /(1+2 \mathrm{r})$} \\
\cline { 2 - 3 } & for $\mathrm{r}_{1}=5.75 \%$ & for $_{2}=11.5 \%$ \\
\hline Shiller method & 3.031473 & 1.125682 \\
Derivative method & 2.98374 & 1.6324 \\
\hline
\end{tabular}

As $\sigma\left(\Delta \mathrm{p}_{\mathrm{t}}\right)=5.158392$, it is largely greater than $\sigma\left(\Delta \mathrm{d}_{\mathrm{t}}\right) / \sqrt{2 r^{3}} /(1+2 \mathrm{r})$. 
Consequently, the third and final inequality is also widely violated and further confirms the results of the first two inequalities. Indeed, the violation of all the advanced inequalities by Shiller variance bounds tests can rule on the fact that the prices of securities listed on the Tunis Stock Exchange exhibit excessive volatility that help generating waves of speculative bubbles.

\section{Conclusion}

In this paper, we treated the theory of heterogeneous expectations and operators' strategic exchange on the stock market for the sake to analyze the information impact on the market transactions behavior. Borrowing the methodology of the variance bounds model initiated by Shiller (2001), The results pointed that the Tunisian stock market exhibits such an excessive volatility which leads to generate an emergence of speculative bubbles waves, favoring consequently the state of irrationality of market operators.

\section{References}

Admati, A., \& Pfleiderer, P. (1988). A theory of intraday pattern: Volume and price variability. Review of Financial Studies, 1(1), 3-40. http://dx.doi.org/10.1093/rfs/1.1.3

Ai, H. (2010). Information quality and long-run risk: Asset pricing implications. Journal of Finance, 65(4) 1333-1368. http://dx.doi:10.1111/j.1540-6261.2010.01572

Alti, A. T., \& Lock, P. C. (2014). Biased beliefs, asset prices, and investment: A structural approach. Journal of Finance, 69(1), 325-361. http://dx.doi:10.1111/jofi.12089

Anderson, T. (1996). Return volatility and trading volume. Journal of Finance, 51, 169-204. http://dx.doi.org/10.1111/j.1540-6261.1996.tb05206.x

Asparouhova, E., Bessem, B. H., \& Kalcheva, I. (2013). Noisy Prices and Inference Regarding Returns. Journal of Finance, 68, 665-714. http://dx.doi.org/10.1111/jofi.12010

Barberis, N., Shleifer, A., \& Vishny, R. (1998). A model of investor sentiment. Journal of Financial Economics, 49, 307 -348. http://dx.doi.org/10.1016/S0304-405X(98)00027-0

Bazak, S., \& Makarov, D. (2014). Strategic Asset Allocation in Money Management. Journal of Finance, 69(1), 179-217. http://dx.doi.org/10.1111/jofi.12106

Benartzy, S., \& Thaler, R. (2002). How much is investor autonomy worth? Journal of Finance, 57(4), 1593-1616. http://dx.doi.org/10.1111/1540-6261.00472

Bertrand, M., \& Morse, A. (2012). Information disclosure, cognitive biases, and payday borrowing. Journal of Finance, 66(6), 1865-1891. http://dx.doi.org/10.1111/j.1540-6261.2011.01698.x

Biais, B. (1993). Price formation and equilibrium in fragmented and centralized markets. Journal of Finance, 48(1), 157-185. http://dx.doi.org/10.1111/j.1540-6261.1993.tb04705.x

Biais, B., Hillion, P., \& Spatt, C. (1995). An empirical analysis of the limit order book and the order flow in the Paris Bourse. Journal of Finance, 50(5), 1655-1689. http://dx.doi.10.1111/j.1540-6261.1995.tb05192.x

Bikhchandani, B., Hirschleifer, D., \& Welch, I. (1992). A theory of fads, faction, custom and cultural changes as informational cascades. Journal of Political Economy, 100(3), 992-1026. http://dx.doi.org/10.1086/261849

Black, F. (1986). Noise. Journal of Finance, 41(3), 529-543. http://dx.doi.org/10.2307/2328481

Blanchard, O. J., \& Watson, M. W. (1982). Bubbles, rational expectations financial. In P. Wachtel (Ed.), Crises in the economic and financial structure. Lexington books. http://dx.doi.org/10.3386/w0945

Blanchard, O. J., \& Watson, M. W. (1984). Bulles, anticipations rationnelles et marches financiers. Annales de l'INSEE, 54.

Bloomfield, R., O’Hara, M., \& Saar, G. (2009). How noise trading affects markets: An experimental analysis? Review of Financial Studies, 22(6), 2275-2302. http://dx.doi.org/10.1093/rfs/hhn102

Bodie, Z., \& Merton, R. (2001). Finance. USA: Prentice-Hall, Inc.

Brockman, P., \& Chung, D. Y. (2000). An empirical investigation of trading asymmetric information and heterogeneous prior beliefs. Journal of Empirical Finance, 7(5), 417-454. http://dx.doi.org/10.1016/S0927-5398(00)00020-7

Buraschi, A., Trojani, F., \& Vedolin, A. (2014). When Uncertainty blows in the Orchard: Co movement and equilibrium volatility risk premium. Journal of Finance, 19, 101-137. http://dx.doi.org/10.1111/jofi.12095

Campbell, J., \& Kyle, A. (1993). Smart money, noise trading, and stock price behavior. Review Economic 
Studies, 60(202), 1-34. http://dx.doi.org/10.3386/t0071.

Campbell, J., \& Shiller, J. C. (1988). Stock prices, earnings and expected dividends. Journal of Finance, 43(3), 661-676. http://dx.doi.org/10.1111/j.1540-6261.1988.tb04598.x

Chordia, T., \& Swaminathan, L. (2000). Trading volume and Cross autocorrelation in stock returns. Journal of Finance, 55(2), 913-935. http://dx.doi.org/10.1111/0022-1082.00231

Choudhry, M. (2007). Bank asset and liability management: Strategy, trading, Analysis. Printed by Saik Wah Press Pte Ltd.

Clement, M. (2004). Financial analyst characteristics and Herding Behavior in Forecasting. Journal of Finance, 60(1), 307-341. http://dx.doi.org/10.1111/j.1540-6261.2005.00731.x

Copeland, T. E., \& Galai, D. (1983). Information effects of the bid -ask spread. Journal of Finance, 38(5), 1457-1469. http://dx.doi.org/10.1111/j.1540-6261.1983.tb03834.x

Cutler, D., Poterba, J., \& Summers, L. (1989). What moves stock prices? Journal of Portfolio Management, 15(3), 4-12. http://dx.doi.org/10.3905/jpm.1989.409212

Daniel, K., \& Titman, S. (2008). Market Reactions to Tangible and Intangible Information. Journal of Finance, 61(4), 1605-1643. http://dx.doi.org/ 10.1111/j.1540-6261.2006.00884.x

Easley, D., \& O'Hara, M. (1987). Price, trade size and information in securities markets. Journal of Financial Economics, 19, 69-90. http://dx.doi.org/10.1016/0304-405X(87)90029-8

Easley, D., \& O'Hara, M. (2010). Microstructure and ambiguity. Journal of Finance, 65(5), 1817-1846. http://dx.doi.org/10.1111/j.1540-6261.2010.01595.x

Foster, F. D., \& Viswanathan, S. (1993). The effect of public informational competition trading volume and price volatility. Review of Financial Studies, 6, 23-56. http://dx.doi.org/10.1093/rfs/6.1.23

Foucault, T. (1999). Order flow composition and trading casts in a dynamic limit order market. Journal of Financial Markets, 2, 99-134. http://dx.doi.org/10.1016/S1386-4181(98)00012-3

Foucault, T., Sraer, D., \& Thesmar, D. J. (2011). Individual investors and volatility. Journal of Finance, 66, 1369-1406. http://dx.doi.org/10.1111/j.1540-6261.2011.01668.x

Garman, M. (1976). Market microstructure. Journal of Financial Economics, 3, 257-275.

Glosten, L. R., \& Milgrom, P. R. (1985). Bid, ask and transaction prices in a specialist market with heterogeneously informed traders. Journal of Financial Economics, 14, 71-100. http://dx.doi.org/10.1016/0304-405X(85)90044-3

Hailer, A., \& Stoll, H. R. (1989). Market structure and transaction Costs, implied spreads in the German stock market. Journal of Banking and Finance, 13, 697-708. http://dx.doi.org/10.1016/0378-4266(89)90038-1

Hirshleifer, D., \& Subrahmanyam, A. (1998). Security analysis and trading pattern when investor receives $\begin{array}{llll}\text { information before other. Journal of } & \text { Finance, 49, 1665-1668. }\end{array}$ http://dx.doi.org/10.1111/j.1540-6261.1994.tb04777.x

Ho, T. S., \& Stoll, H. R. (1983). The dynamics of dealer markets under competition. Journal of Finance, 38 , 1053-1074. http://dx.doi.org/10.1111/j.1540-6261.1983.tb02282.x

Hu, G. X., Pan, J., \& Wang, J. (2013). Noise as information for illiquidity. Journal of Finance, 68, 2341-2382. http://dx.doi.org/10.1111/jofi.12083

Illeditcsh, P. K. (2012). Ambiguous information, portfolio inertia, and excess volatility. Journal of Finance, 66(6), 2213-2243. http://dx.doi.org/10.1111/j.1540-6261.2011.01693.x

Kaniel, R., Saar, G., \& Titman, S. (2008). Individual investor trading and stock returns. Journal of Finance, 43, 661-676. http://dx.doi.org/10.1111/j.1540-6261.2008.01316.x

Kodres, L., \& Pritsker, M. (2001). A rational expectations model of financial contagion. Journal of Finance, 57(2), 769-799. http://dx.doi.org/ 10.2139/ssrn.148769

Kogan, L., Ross, S. A., Wang, J., \& Westerfiled, M. M. (2006). The Price impact and survival of irrational traders. Journal of Finance, 61, 195-230. http://dx.doi.org/10.1111/j.1540-6261.2006.00834.x

Kyle, A. (1985). Continuous auction and insider trading. Economica, 53, 1315-1335. http://dx.doi.org/10.2307/1913210 
Kyle, A. (1989). Informed speculation with imperfect competition. Review of Economic Studies, 5, 317-355. http://dx.doi.org/10.2307/2297551

Lawrence, E. H., \& Ventakech, P. (2005). Trading costs and returns. Journal of Financial Markets, 8, 25-67.

Lee, Y. T., Lin, J. C., \& Liu, Y. J. (1999). Trading patterns of big versus small players in an emerging market. Journal of Banking and Finance, 23(5), 701-726. http://dx.doi.org/10.1016/S0378-4266(98)00116-2

Leland, H. (1992). Insider trading. Journal of Political Economic, 100(4), 859-887. http://dx.doi.org/10.1086/261843

Leroy, R., \& Porter, R. (1981). The present-value relation: Tests based on implied variance bounds. Econometrica, 49, 555-574. http://dx.doi.org/10.2307/1911512

Linnainmaa, J. T. (2010). Do limit orders alter inferences about investor performance and behavior? Journal of Finance, 65, 1473-1506. http://dx.doi.org/10.1111/j.1540-6261.2010.01576.x

Loewenstein, M., \& Willard, G. A. (2006). The limits of investor behavior. Journal of Finance, 61, 231-258. http://dx.doi.org/10.1111/j.1540-6261.2006.00835.x

Lynch, A., \& Musto, D. (2003). How investors interpret past returns. Journal of Finance, 58(5), 2033-2059. http://dx.doi.org/10.1111/1540-6261.00596

Orlean, A. (1989). Pour une approche cognitive des conventions. Economiques, 40(2), 241-272. http://dx.doi.org/10.3406/reco.1989.409140

Orlean, A. (1990). Le rôle des influences interpersonnelles dans la détermination des cours boursiers. Revue Economique, 41(5), 839-868. http://dx.doi.org/10.3406/reco.1990.409241

Orlean, A. (1992). Contagion des opinions et fonctionnement des marchés financiers. Revue Economique, 4, 685-697. http://dx.doi.org/10.3406/reco.1992.409384

Peress, J. (2010). Product market competition, insider trading, and stock market efficiency. Journal of Finance, 65, 1-44. http://dx.doi.org/10.1111/j.1540-6261.2009.01522.x

Roll, R. (1984). A simple implicit measure of the effective bid-ask spread in an efficient Market. Journal of Finance, 39, 1127-1139. http://dx.doi.org/10.1111/j.1540-6261.1981.tb04890.x

Scherbina, A. (2004). Analyst disagreement, forecast bias and stock returns. Harvard Business School, working paper series, N05, 2003. http://dx.doi.org/10.1086/261843

Shiller, R. (2001). Bubbles, Human judgment and Expert Opinion. Journal of Social, Political and Economic Studies, 305-320. http://dx.doi.org/10.2469/faj.v58.n3.2535

Shiller, R. J. (1981). Do stock prices move too much be justified by subsequent changes in dividends? American Economic Review, 71, 421-436. http://dx.doi.org/10.1086/261843

Shiller, R. J. (1984). Stock prices and social dynamics. Economic Activity, 2, 457-498. http://dx.doi.org/10.2307/2534436

Shiller, R. J. (1999). Measuring bubble expectations and investor confidence. Journal of Finance. Working paper 7008. http://dx.doi.org/10.1086/261843

Shiller, R. J. (2000a). Market volatility. MIT Press.

Shiller, R. J. (2000b). Irrational exuberance. Princeton UP, Oxford.

Shiller, R. J. (2000c). Measuring bubble expectation and investor confidence. Journal of Psychology and Financial Markets, 1(1), 49-60. http://dx.doi.org/10.1207/S15327760JPFM0101_05

Shleifer, A. (2000). Inefficient markets: An introduction to behavioral finance. Oxford university press. http://dx.doi.org/10.1257/jep.4.2.19

Shleifer, A., \& Summers, L. (1990). The noise trader approach to finance. Journal of Economic Perspectives, 4, 19-33. http://dx.doi.org/10.1257/jep.4.2.19

Shleifer, A., \& Vishny, R. (1997). The Limits of Arbitrage. Journal of Finance, 52, 35-55. http://dx.doi.org/10.1111/j.1540-6261.1997.tb03807.x

Smirlock. M., \& Starks, L. (1986). An empirical analysis of the stock price volume relationship. Journal of Banking and Finance, 12, 31-41. http://dx.doi.org/10.1016/0378-4266(88)90048-9

Stoll, H. (1989). Inferring the components of the bid ask spread: Theory and empirical tests. Journal of Finance, 
44, 115-125. http://dx.doi.org/10.1111/j.1540-6261.1989.tb02407.x

Summers, L. (1986). Does the stocks market rationally reflect fundamental values? Journal of Finance, 41, 591-601. http://dx.doi.org/10.1111/j.1540-6261.1986.tb04519.x

Von Neumann, J., \& Morgenstern, D. (1944). Theory of games and Economic behavior. Princeton University Press.

Wang, A. (1998). Strategic trading, asymmetric information and heterogeneous prior belief. Journal of Financial Markets, 1(3-4), 321-352. http://dx.doi.org/10.1016/S1386-4181(97)00007-4

Wang, J., \& Lo, A. W. (2006). Trading volume: Implication of an intertemporal capital asset pricing model. Journal of Finance, 61(6), 2805-2840. http://dx.doi.org/10.1111/j.1540-6261.2006.01005.x

Zhang, X. F. (2006). Information uncertainty and stock returns. Journal of Finance, 61, $105-139$. http://dx.doi.org/10.1111/j.1540-6261.2006.00831.x

Ziegler, A. (2001). Optimal portfolio choice under heterogeneous beliefs. European Finance Review, 4, 45-59. http://dx.doi.org/10.1111/j.1540-6261.2006.00831.x

\section{Copyrights}

Copyright for this article is retained by the author(s), with first publication rights granted to the journal.

This is an open-access article distributed under the terms and conditions of the Creative Commons Attribution license (http://creativecommons.org/licenses/by/3.0/). 